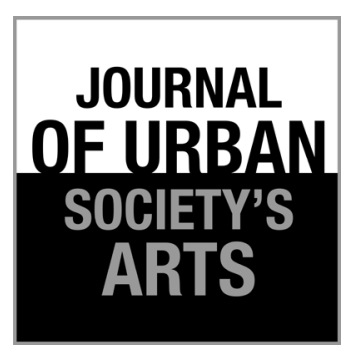

Volume 7 Nomor 1 , April 2020: 15-20

\section{Indonesian Documentary: A Theoretical Review about Truth Claims Perspective}

\section{Renta Vulkanita Hasan}

Fakultas Ilmu Budaya - Universitas Jember

Jln. Kalimantan No. 37. Kampus Tegal Boto, Jember 68121

Email: rentavulkanita.sastra@unej.ac.id; HP.: +6281328880986

\begin{abstract}
A documentary is a type of film that tends to be defined as a recording of reality that embedded in moving images. The documentary cannot be separated from the role of the filmmaker because they construct reality and issues by assembling footage into narratives. Furthermore, narratives are that accompanied by the social realm as fact and the role of filmmakers in the documentary bring a notion toward truth claims. Truth claims on the documentary need to be investigated because it involves two aspects: facts and filmmakers. Investigations are conducted to look for possibilities, whether another side of the documentary is about trustworthiness. The first step of the investigation is to conduct a theoretical review. Therefore, a theoretical review is needed to find previous research that has notions about truth claim of documentary from a diverse perspective. The method of this investigation which compares some previous approaches to cognitive film approach of where it is initially put on the elements of documentary and filmmakers is shifted to the perspective placed on the film text by engaging to the audience. This research has an outcome that is possible to shift perspective from truth claims into trustworthiness through evoking the audience in experienceing the film clues.
\end{abstract}

Keywords: documentary; trustworthiness; cognitive film

\begin{abstract}
ABSTRAK
Film Dokumenter Indonesia: Tinjauan Teoritis Tentang Perspektif Klaim Kebenaran. Film dokumenter adalah salah satu jenis film yang cenderung diartikan sebagai rekaman realitas yang tertanam dalam gambar bergerak. Film dokumenter tidak lepas dari peran pembuat film karena mengkonstruksi realitas dan persoalan dengan merangkai rekaman menjadi narasi. Selanjutnya narasi yang dibarengi dengan ranah sosial sebagai fakta dan peran sineas dalam dokumenter membawa pemahaman terhadap klaim kebenaran. Klaim kebenaran terhadap dokumenter perlu diteliti karena menyangkut dua aspek: fakta dan pembuat film. Investigasi dilakukan untuk mencari kemungkinan, apakah sisi lain dari dokumenter itu adalah tentang kepercayaan. Langkah pertama investigasi adalah melakukan tinjauan teoritis. Oleh karena itu, diperlukan kajian teoritis untuk menemukan penelitian sebelumnya yang memiliki pengertian tentang klaim kebenaran dokumenter dari perspektif yang beragam. Metode investigasi ini yang membandingkan beberapa pendekatan sebelumnya dengan pendekatan film kognitif yang awalnya ditempatkan pada unsur-unsur dokumenter dan pembuat film bergeser ke perspektif yang ditempatkan pada teks film dengan melibatkan penonton. Penelitian ini memiliki hasil yang memungkinkan untuk mengubah perspektif dari klaim kebenaran menjadi dapat dipercaya melalui penggalian pengalaman penonton kepada petunjuk film.
\end{abstract}

Kata kunci: dokumenter; kepercayaan; film kognitif 


\section{Introduction}

Indonesian cinema, in this case is documentary, categorized as an object with two different realms. The notion partially implied that Indonesian cinema during the New Order era tends to be regarded as a medium of propaganda, rather than an artistic dimension (Sen and Hill; 2007). Therefore, censorship imposed strict enough on it. Mostly Indonesian cinema that have critical exposure are not only failed in the popularity stakes, but that also fell through to get its position. Sen even tends to do a critique of the regime in power at the time that influences Indonesian cinema (Sen and Hill 2007: 146). Once regime claims documentary as facts, they intrigued to put issue upon film text in order to scrutiny the audience. However, film text flourished as audience portends whereas it's parallel to how audience understands to. Hence, audience have their own perspective toward documentary and its issue that rely on.

Audience perspective, furthermore, creates experiences through film texts of documentary. Perspective is posited by filmic text that later brings audience on a specific experience to understand in every clue rather claims. Experiencing movie obviously makes audience on their urge to finding the text clues, however, interjecting it as well. Cognitive process possibly makes audience have their own decision during movie, moreover, through interjecting and mending the conclusion. Trustworthiness is, rather than claims, being supposed as term that enables documentary prominently perceived as film text instead of another.

Regarding the film text as clues, Documentary have gestural elements and features throughout its plot (Adorno, 2002: 16). The element is attached and shows the specific situation in the form of textual cues that must be understood to find the film clues. Understanding and interpreting documentary are perceiver activity that plays a central role. Therefore, understanding is an activity that is mediated by transformative action, both bottom-up, the command (mandatory) to the psychological process automatically or top-down, in the form of psychological processes toward command (mandatory) conceptual strategically (Bordwell, 1991: 2). Sensory data of documentary, on the one hand furnishes materials for the process of perception inferentially, and cognition in creating meaning. In conclusion, sensory data creates meaning for documentary, so that the meaning of documentary is not found but created (Bordwell, 1991: 3).

The stage is determined by the following reasons (1) since documentary tries defined and theorized, then when it is appeared such as statement calling some issues; (2) the issues that arise are driven by a variety of viewpoints that led to the claim that documentary is identical with the truth refers to (a) relationship between documentary and facts and (b) relationship between documentary and filmmakers. Hence, theoretical review is conducted to know how it grows whereby scholars theorized documentary. Review is undertaken through conceptual grooves built into three stages: (1) truth claims; (2) key positions; and (3) cognitive film approach.

\section{Truth Claims}

Growing attention to documentary practice, that is often characterized by the emergence of the issue. An important issue that emerged in the attention is documentary truth claims. Documentary truth claims has several important positions born of the previous research that lays the truth of a documentary on the two relationships: (1) documentary and its realm and (2) the role of documentary filmmakers (Nichols, 2001; Nash, 2010: 28). Those are important to reveal the keys position.

\section{Key Position}

\section{Creative Treatment}

The position that obviously born from the documentary realm is a creative treatment. John Grierson (1972) in an interview transcribed by Elizabeth Sussex entitled Grierson on Documentary: The Last Interview, claimed in a documentary must contain certain issues of fact recorded. Grierson approaches to a definition of documentary is the practical approach to expository style expository to 
imply truth claims. The formulation known as "the creative treatment of actuality” (Sussex, 1972: 24). Grierson in an attempt to criticize the truth in the previous documentary (which evolved in the era Flaherty), expressed the opinion that documentary is not just emphasizes the actuality in which only presents the events of ethnographic through scenes of poetic. That is, the recording of events also has to present social issues conducted persuasively (Ellis, 1989: 5). In addition to the emphasis on social issues, Grierson assumes documentary in the works of Flaherty less attractive because it is too poetic, and has no sounds. Grierson said documentary that is presented by Flaherty could be more interesting by giving the "creative treatment". Creative treatment can be applied through the editing process with emphasis on the camera angle that shows the existence of social issues, as well as add sounds (voices) to reinforce the focus is (Rotha in Breitrose, 1974: 25). Recording events that are equipped with sounds (voices) far more beneficial because it may lead to the concept of a specific object, and can also be used as a medium of learning (Grierson in Sussex, 1972: 25).

Lucas Hilderbrand (2009), in line with Grierson, refers to the term creative treatment that then developed in accordance with the experimental documentary does. Through the same approach with Grierson, Hilderbrand created formulation of the term named "creative treatment for the experience" through the work of experimental documentaries (Hilderbrand, 2009: 2-3).

Sheila Curran-Bernard (2007) in his book "Documentary Storytelling", formulated in line with that understanding. Through textual analysis of the process of making a documentary, Bernard yield a formula which states that the documentary should involve a range of creative options on the structure of the film, the viewing angle, balance, style, character, and so the story is presented (Bernard, 2007: 1). Bernard in the development of the documentary also contribute to formulating Documentary Storytelling phrase. Bernard indicates documentary today increasingly diverse. Bernard offers strategies to achieve quality of documentary through the creation narrative story and unique skills that convey not only the subject of the film, but also themes and writing are done honestly (Bernard, 2007: xiii). This statement encourages us to look back Grierson formulation about "the creative treatment" which he said should be applied to establish the value of a documentary. Creative treatment as if stressed, not merely using the camera to record each incident without doing anything, but also the role of legitimacy such as what should be appointed through creative techniques in a film that can indicate issues that are emphasized. Bernard formulation's which in line with that understanding, affirmed that documentary should involve a range of creative options on the structure of the film, angle, balance, style, character, and the story is presented (Bernard, 2007: 1). Bernard seems to put creative documentary offered parallel to Grierson. Even through her series Documentary Storytelling, Bernard tried to construct a pattern of documentary making for if it was located in this relation.

Creative treatment on documentary is considered to have an advantage in the aspect of its style. Thanks to the creative treatment, documentary created into a form of a film that has two main aspects, messages and aesthetic throughout its sounds such as speech. Regarding to the creative treatment, speech is considered to have a role in the effort of delivering message through the film clues (Nichols, 1988: 49). Nevertheless, using speech is no comprehensive explanation (beyond rhetoric Voice of God formulated by Bill Nichols) how documentary is identical with speech.

\section{Social Representation}

The second position that born from documentary realm is a social representation. Referring to the explanation of the previous chapter, Nichols (2001) states that the documentary is partially social representation. Nichols also stated explicitly that the documentary is a reproduction of reality of the human being in the world they inhabit to (Nichols, 2001: 1). Nichols uses four consideration of viewpoints in its approach to define documentary. Four viewpoints that are: (1) institutions; (2) practitioner / actors; (3) text (film / video); and (4) audience (Nichols, 2001: 22). However, Nichols has not been explicitly state 
that social representation is an objective aspect to describe documentary as truth.

Patricia Aufderheide (2007) states that documentary is representational reality of the world (Aufderheide, 2007: 9-10). However, by her definition, Aufderheide also questioned the boundary between fact with fiction within documentary (Aufderheide, 2007: 2). Furthermore, She noticed to documentary as film that tells the story of life, however, it is given representation honestly and in good faith, but it will be discussed which has never completed. Aufderheide statement indicates that documentary is not objectively enough to be claimed as the truth.

Keith Beattie (2004) states that a documentary is the act of recording on real events that happened so that the tape was regarded as a representation of reality (Beattie, 2004: 13). Representing event seems that is considered Beattie as truth in the documentary. If it is claimed to be the truth, then the problems on the position is regarded to objectivity. The more documentary represents the event, the harder it is determined as reality because of its appearance tends to be simulacra (Baudrillard in Cavallaro, 2004, 372).

Theoretically, the difference between the position of the creative treatment with representations lies in the role of presenting documentary. Creative treatment has been to develop a specific attribute to an event so that it appears as if the issues stated that certain situations have arisen to develop into a phenomenon (Grierson in Sussex, 1972: 2425). While the representation considers that the documentary is presenting reality. Documentary, in this perspective, has a meaning as something that moved into a new shape in the form of recordings. That is, the representation shall transfer to a new form called documentary (Nichols, 2001: 5).

\section{Filmmakers Expertise}

Filmmakers expertise in a particular field are considered competent in doing reconstruction (Ruby, 1992). Brian Winston (2000) through this position find a model called "continuum of reconstruction" (reconstruction continuum) (Winston, 2000: 105-106 of Aaltonen and Kortti, 2015: 116-117).
Aaltonen and Kortti (2015) say that the history of putting facts on the concept of reconstruction of the events involving the expertise filmmakers to show the truth. In this case, filmmakers who have professional expertise, for example, are considered competent to find and create the material for documentary through their intervention against the recorded. Through a pragmatic analysis, Aaltonen and Kortti want to show contributions in the history of documentary filmmaking in general. It is also to show how the development of the documentary was affecting the nature of historical documentation on television. Aaltonen and Kortti show that documentary filmmakers contribute expertise in the delivery of the truth through historical reconstruction, but still they have not touched the area of objectivity.

Jay Ruby (1992) states that the action filmmakers to use their expertise, such as profession, is easy to make claims in the documentary. Ruby says that documentary filmmakers who have expertise try to find and to think about the visual images as means of social construction through documentary (Ruby, 1992: 42).

Along with Ruby, Phillip Rosen (1993) states that a documentary is a historical reconstruction that was built by the filmmakers to present reality through tradition and technology(Rosen, 1993: 88 -89). Based on the statement Ruby and Rosen, filmmakers expertise have drawbacks such as concerns about subjectivity. That is, filmmakers feared to make the documentary as a subject that has been reconstructed to accommodate their interests.

\section{Access to Social Actors (Witness)}

The other position is access to social actors (witness). This position is to formulate a model named "consent". Pryluck (1988) states that the consent is the basis of trust participants to play a role as social actors (Pryluck, 1988: 256). Initially, approval required in the creation of documentaries in the context of ethics. The approval apparently tends to be important as documentary parts. That can also be convinced as actuality. Referring to the statement Willemian Sander (2012) about survey of documentary filmmakers on dealing with par- 
ticipants stated that openness, trust, and approval of the witness are important for filmmakers to interpret actuality or facts. Sanders interprets this pattern as a situation of trust and understanding through ongoing communication with the term cooperative partnership (Sanders, 2012: 393).

\section{Cognitive Film Approach to Inquiry The Truth Claims}

Determination theory is part of the conceptualization that aims to reveal the other side of the truth in a documentary that is not only placed on (1) the creative treatment; (2) the representation; (3) filmmaker expertise; and (4) social access. The other side of documentary truth can be found through research efforts to use new perspective to look at the documentary through new relationships, between documentary and their audience. The new perspective that puts the relation between the documentary and their audience is to see the truth objectively applicable for their audience experience and understanding. There are allegations that audience are reading filmic texts through their experience of everyday life. To prove this assumption, cognitive film approach considers to David Bordwell and Noel Carroll, cognitive perspective to the film with a purpose in it, is allowing it to be filled by a variety of different positions (Plantinga, 2006: 216). According to Bordwell and Carroll, cognitive film approach provides space for documentary to give a new position, such as the trustworthiness of its film texts through audience experience. Cognitive film approach is the basis for cognitive mental structures work to generate understanding of film texts that will be read by the audience, such as gestures and features. Film texts are covering the area of motion gesture that associated with facial expressions, hand gestures and foot movements, and voices. While, the area of artistic includes clothing, property, and setting.

\section{Conclusion}

This theoretical review suggests that the development of documentary does not simply stop at one tradition. Discourse that emerged in the period to the next provides an opportunity that theorizing documentary is unfolding. The dynamic nature is what makes documentary has a chance to be seen as a circumstance inseparable, wherein documentary and its audience meet in a space built with trustworthy to the film text. Objects in the space between documentary and audience built by all aspects inherent to documentary and the audience experience. Trustworthiness is the result of this theoretical review that might be considered. Further research is needed to follow up this result in order to investigate trustworthiness as documentary perspective.

\section{References}

Aaltonen, J. and Kortti, J., (2015). From evidence to re-enactment: history, television and documentary film, Journal of Media Practice. 16(12), 108-125.

Aguilar, G, (2013). "The Documentary: Between Reality and Fiction, Between First and Third Person" in Andermann, J. London: Jens Andermann and Álvaro Fernández Bravo (eds). New Argentine and Brazilian Cinema. New York: Palgrave.

Antonacopoulou, E.P. and Gabriel, Y., (2001). Emotion, learning and organizational change: Towards an integration of psychoanalytic and other perspective. Journal of Organizational Change Management. 14(5), 435

Aufderheide, P., (2007). Documentary Film a Very Short Introduction. New York: Oxford University Press.

Beattie, K., (2004). Documentary Screen Non-Fiction Film and Television. New York: Palgrave.

Bergman, T., (2004). Personal narrative, dialogism, and the performance of "truth" in complaints of a dutiful daughter. Journal of Text and Performance Quarterly, 24 (1), 3-20.

Bernard, S.C., (2007). Documentary Storytelling. Oxford: Elsevier.

Bordwell, D., (1985). Narration in The Fiction Film. Wisconsin: The University of Wisconsin Press.

Bordwell, D., and R. Burton Palmer (ed), (1989). Historical Poetic of Cinema (The Cinematic 
Text: Methods and Approaches. Georgia State Literary Studies. 3. 369.

Bordwell, D., and Carroll, N., (1996). Post-Theory: Reconstructing Film Studies. Wisconsin: The University of Wisconsin Press.

Bordwell, D., (1991). Making Meaning: Iinference And Rhetoric In The Interpretation of Cinema. Cambridge: Harvard University Press.

Carroll, N., (1997). The Essence of Cinema. Philosophical Studies: An International. Journal for Philosophy in the Analytic Tradition, 89( 2/3), 323-330

Carroll, N., (1996). Theorizing The Moving Image. Cambridge: Cambridge University Press.

Carroll, N., (2003). Engaging The Moving Image. New Haven: Yale University Press.

Cavallaro, D., (2004). Critical and Cultural Theory. Yogyakarta: Niagara.

De Caro, M. and E. Terrone, (2016). The View From Outside: On A Distinctively Cinematic Achievement, Philosophy and Social Criticism. 42(2), 154-170.

Ellis, J.C., (1989). The Documentary Idea: A Critical History of English-Language Documentary Film and Video. New Jersey: Prentice Hall.

Hilderbrand, L., (2009). Introduction Experiment In Documentary: Contradiction, Uncertainty, Change. Millenium Film Journal. Spring; 5(1), 2.

Nash, K, (2010). Exploring Power And Trust In Documentary: A Study of Tom Zubrycki's Molly and Mobarak. SDF 4 (1), 21-33.

Nichols, B., (2001). Introduction to Documentary. Bloomington: Indiana University Press.

Nichols, B., (2008). Documentary Reenactment and the Fantasmatic Subject. Critical Inquiry. 35(1), 72-89

Nordholt, H. S., (2007). The State On The Skin: Clothes, Shoes, and Neatness In (colonial) Indonesia. Asian Studies Review, 21(1), 19-39. DOI: $10.1080 / 03147539708713139$

Plantinga, C.R., (1997). Rhetoric and Representation in Nonfiction Film. Cambridge: Cambridge University Press.
Persson, P., (2003). Understanding Cinema: A Psychological Theory of Moving Imagery. Cambridge: Cambridge University Press.

Renov, M., (1993). Theorizing Documentary. London: Routledge.

Rosenthal, A. (ed). (1988). New Challenge for Documentary: The Voice of Documentary. Berkeley: University of California.

Rotha, P. and Breitrose, H. (ed)., (1974). Documentary Diary. Film Quarterly, 27(3), $52-54$

Ruby, J., (1992). Speaking For, Speaking About, Speaking With, or Speaking Alongside: An Anthropological and Documentary Dilemma, Journal of Film and Video, 44(1/2), 42-66.

Sanders, W., (2012). The Aggie Will Come First Indeed. A Survey on Documentary Filmmakers Dealing with Participants. New Review of Film and Television Studies. 10(3), 387-408.

Sen, K. and Hill, D. T., (2007). Media, Culture, and Politics in Indonesia. Jakarta: Equinox.

Sussex, E., (1972). Grierson on Documentary: The Last Interview. Film Quarterly. 26(1), 24.

Winston, B., (1999). Documentary: How the Myth Was Deconstructed. Wide Angle. 21(2), 71-86.

Willis, G., Royston, P., \& Bercini, D. (1991). The Use of Verbal Report Methods In The Development And Testing of Survey Questionnaires. Applied Cognitive Psychology. 5, 251-267.

\section{Website}

Axemaker, S., (2015). Early Silent Documentaries Real Life Adventure Cinema (internet), Independent Lens, <http://www.pbs. org/independentlens/blog/early-silentdocumentaries-real-life-adventure-cinema/>.

Enticknap, L., (2016). Grierson, John (1898-1972) (internet), Screen Online, <http://www. screenonline.org.uk/people/id/454202/> 